\title{
Groundwater potentiality mapping in the Sinai Peninsula, Egypt, using remote sensing and GIS-watershed-based modeling
}

\author{
Hossam H. Elewa • Atef A. Qaddah
}

\begin{abstract}
Systematic planning for groundwater exploration using modern techniques is essential for the proper utilization, protection and management of this vital resource. Enhanced Thematic Mapper Plus (ETM+) images, a geographic information system (GIS), a watershed modeling system (WMS) and weighted spatial probability modeling (WSPM) were integrated to identify the groundwater potential areas in the Sinai Peninsula, Egypt. Eight pertinent thematic layers were built in a GIS and assigned appropriate rankings. Layers considered were: rainfall, net groundwater recharge, lithology or infiltration, lineament density, slope, drainage density, depth to groundwater, and water quality. All these themes were assigned weights according to their relative importance to groundwater potentiality and their corresponding normalized weights were obtained based on their effectiveness factors. The groundwater potentiality map was finally produced by WSPM. This map comprises five gradational groundwater potentiality classes ranging from very high to very low. The validity of this unbiased GISbased model was tested by correlating its results with the published hydrogeological map of Egypt and the actual borehole yields, where a concordant justification was reached. The map declared that the Sinai Peninsula is generally of moderate groundwater potentiality, where this class encompasses an area of $33,120 \mathrm{~km}^{2}$ which represents $52 \%$ of its total area.
\end{abstract}

Received: 6 January 2010 / Accepted: 7 January 2011

Published online: 12 February 2011

(C) Springer-Verlag 2011

H. H. Elewa (-)

National Authority for Remote Sensing and Space Sciences,

Water Resources Dept. (NARSS),

P.O. Box1564, 11769, Alf-Maskan, Cairo, Egypt

e-mail: hossh2@yahoo.com

Tel.: +201-05831735

Fax: $+202-26225800$

\section{A. A. Qaddah}

Egyptian Environmental Affairs Agency (EEAA), Environmental and GIS Dept.

Teraat El Mansuriyah St., El-Mansura, Egypt

e-mail: aaq_geo@hotmail.com
Keywords Egypt - Remote sensing · Watershed modeling · Geographic information system · Groundwater potentiality mapping

\section{Introduction}

More than $94 \%$ of Egyptian territory is desert land. The magnitude of desertification as a result of water scarcity is a major challenge for the government. A large-scale developmental programme is now occurring on the Sinai Peninsula, where the National Sinai Development Plan (NSDP) for 1994-2017 envisages the development of about 100,000 hectares (ha) of agricultural land, thanks to the construction of Al-Salam (peace) Canal (ICG 2007). The aim is to divert part of the waters of the River Nile Delta eastwards, which would make it possible to irrigate a strip of land in North Sinai, between the Suez Canal and the eastern international border, in a project to create a major agricultural zone. Investment was planned to reach 75 billion Egyptian pounds ( $\$ 13$ billion) by 2017 . Tourism and petroleum industries are the major developmental activities of the central and southern Sinai.

Upgrading the living standards of Sinai's population in the last few decades has caused an increase in water demand. However, water is a significant problem in Sinai. The ElArish, Sheikh Zuwaid and Rafah regions produce mainly fruits and vegetables for the tourism markets of the south but the small farmers depend on a combination of over-exploited groundwater and rainwater, which has been diminishing for some years and mainly falls along the coast. The internal deserts need new wells. Drinking water is distributed by tanker-lorries in the absence of a piped distribution network. In some parts of Sinai, the local inhabitants must use salty groundwater as potable water in the face of the water crisis.

Occurrence of groundwater has been studied for many decades using aerial photo interpretation and geophysical techniques, but computer-based analysis of remote sensing (RS) data and geographic information systems (GIS) has rarely been used for groundwater exploration in Egypt. Hence, there is an urgent need for the present work, which mainly concentrates on the location of groundwater exploration in the Sinai Peninsula rather than the traditional hydrogeological mapping. Using an integration of different research tools and techniques, like RS, GIS, 
watershed modeling system (WMS) and weighted spatial probability modeling (WSPM), areas of potential or prospective groundwater resources have been delineated for the first time.

Spatial representation of data used is critical to groundwater-potentiality mapping, and GIS efficiently manipulated the predictive and related analytical capabilities necessary to examine the complex problems of uncertainty. Even so, there is still uncertainty regarding the minimum necessary validation levels that would ensure good WSPM results. In the present study, in addition to using a reasonable number of GIS layers of the most effective factors responsible for the groundwater prospectivity, validation using measured well yield data was performed to check the WSPM results. However, the physically based Soil Conservation Services (SCS) runoff curve number $(\mathrm{CN})$ for simulating the rainfallrunoff-net groundwater recharge within the WMS platform was the intrinsic approach that has not been addressed by the previous researchers.

In this context, an attempt has been made to evaluate the spatial relationships among the different controlling parameters that favor groundwater occurrence in Sinai watersheds. However, drilling boreholes is required to confirm the existence of groundwater potential zones.

Groundwater potentiality mapping of some parts of Sinai using RS and GIS techniques had been conducted by several researchers, among them: El-Shazly et al. 1985; Shata 1992; Kusky et al. 1994; Abd El Rahman 2001; Masoud and Koike 2005; Mills and Shata 2009. El-Shazly et al. (1983) used the geomorphologic features, land cover, vegetation and geologic units as effective parameters in the groundwater investigations of Wadi Araba area of the Eastern Desert of Egypt, whereas El-Baz (1992) used the lineaments, topography and drainage as effective parameters for preliminary assessment of potential environmental damage of groundwater systems due to the Gulf War $(1990,1991)$. They used a limited number of GIS layers and gained somewhat reasonable results. The higher the number of GIS layers used in groundwater potentiality mapping, the higher the accuracy gained.

El-Baz et al. (1992-1995), in a research project conducted jointly between Boston University Center for Remote Sensing (BU/CRS in the USA) and the Desert Research Center (DRC) in Cairo, Egypt, compiled all the satellite images of the Sinai Peninsula, which were enhanced and interpreted. Data from several field excursions were integrated with image data using GIS. The research resulted in the recognition of a dozen sites with potential for groundwater exploration. Smith et al. (1997) used a method which incorporates satellite imagery and GIS to detect areas of likely groundwater in the northern Sinai Peninsula. The technique involves integration of bifurcation ratio, drainage density, stream frequency, slope and precipitation.

The Research Institute for Groundwater (RIGW 1999) constructed the hydrogeological map of Egypt (Scale 1: $2,000,000)$. This map was made on a very small scale from the satellite TM images and hydrogeological and hydrochemical information on groundwater well logs and records of piezometric levels for the mapped portion of
Sinai. The map only elucidated the types of aquifer systems according to their productivity, from highly productive to local and very low productive aquifer. According to this map, the highly productive aquifers are those which acquire an occasional surface recharge from rainfall or surface runoff, whereas the local and very low productive aquifers refer to the aquifers that have insignificant surface recharge and limited subsurface recharge. However, this map is considered as a regional reconnaissance because of its scale and coarseness of data coverage. Japan International Cooperation Agency (JICA 1999), with the collaboration of Water Resources Research Institute of Egypt, conducted a groundwaterresources study, producing tentative hydrogeological maps covering both South and North Sinai. Several layers were used, i.e. borehole and groundwater data, geological data, geomorphological data, vegetation information and landuse maps. The resulting maps were on a scale of 1:500,000. Gheith and Sultan (2000) made an assessment of the renewable groundwater resources of Sinai using remote sensing, digital terrain elevations, and meteorological data. Subsequently, Gheith and Sultan (2001) conducted comprehensive studies to develop, validate, and demonstrate techniques for evaluating the extent of alternative renewable water resources of Wadi El-Arish arising from sporadic precipitation. The methods used were various geochemical and isotopic techniques, surface and groundwater modeling, analysis of Landsat, digital elevation models, seismic and drilling data, and field observations. Milewski et al. (2006) carried out a catchment-based hydrologic model for the Sinai Peninsula using remote sensing and field datasets. Becker et al. (2007) tested an integrated approach for the assessment of the renewable groundwater resources of Sinai. UNDP (United Nations Development Program)/GEF (Global Environment Facility) (2003-2008) funded a project, which investigated the renewable groundwater resources in Sinai. They investigated two main potential water resources: (1) sporadic precipitation that occurs over mountainous areas providing water that resides within the highly fractured basement reservoirs or as surface runoff and/or as subsurface groundwater flow and which ultimately resides in the alluvial aquifers flooring the main valleys, and (2) Nubian Aquifer groundwater channeled through the deep-seated sub-vertical faults and ultimately resides in near-surface alluvial aquifers. They used integrated methodologies involving isotopic techniques $\left({ }^{18} \mathrm{O}, \mathrm{H}\right)$, remote sensing, meteorologic, and surface runoff studies to locate reservoirs in question and to assess their groundwater potentiality.

However, no maps were previously produced depending on the integration of RS, GIS, WMS and WSPM. Such maps should involve all the expected factors contributing to groundwater prospectivity in Sinai, especially the factors concerning the quantified groundwater recharge from rainfall and runoff water. Establishing links between the integrated technologies (RS, GIS, WMS and WSPM) using new data coverage was the prerequisite for constructing a groundwater exploratory map of Sinai. 


\section{Study area and geomorphologic features of the Sinai Peninsula}

The Sinai Peninsula is located in the northeastern portion of Egypt and is bounded by longitudes $32^{\circ} 20^{\prime}-34^{\circ} 52^{\prime} \mathrm{E}$ and latitudes $27^{\circ} 45^{\prime}-31^{\circ} 10^{\prime} \mathrm{N}$. It occupies an area of about $61,000 \mathrm{~km}^{2}$ or about $6 \%$ of Egypt's total area with a population of about 400,000 , which is mainly Bedouin $(60 \%)$ and the rest are located in small cities such as El Arish and Sharm El Sheikh. The Peninsula has a triangular shape; its apex is to the south at Ras Mohammed (south of latitude $28^{\circ}$ ), whereas its base is to the north extending along the Mediterranean coast between Port Said and Rafah for about $210 \mathrm{~km}$ (Fig. 1a and b). Sinai is bounded in the eastern side by the Gulf of Aqaba and the international border and in the west by the Gulf of Suez and the Suez Canal. The southern part of the Peninsula is formed by a complex of high mountains, many of which rise to considerably greater heights than many mountains in the other parts of Egypt such as Gebel Catherina $(2,641 \mathrm{~m}$ above mean sea level, amsl), Um Shomar (2,586 m amsl) and Serbal (2,070 m amsl). Flanking this mountain mass to the north, which forms the northern two-thirds of the Peninsula, is the great Egma limestone plateau, sloping from heights of more than $1,000 \mathrm{~m}$ downwards to the Mediterranean Sea. The mountainous tract in the south is intensively dissected by deep canyon-like wadies draining either to the Gulf of Suez or to the Gulf of Aqaba. Most of the drainage channels of the northern plateau course northwards to the Mediterranean Sea, where the drainage lines are much shallower and more open. The great Wadi El Arish, which collects the drainage from a very large proportion of the total area of the northern plateau, debouches into the Mediterranean Sea, near the town of El Arish (Fig. 1b and d). Hydrographic parameters associated with the drainage basins are given in Table 1 .

The geomorphology of the Sinai Peninsula could be discriminated into five main units, which were first indicated by Shata (1956). These geomorphic units are the southern elevated mountains, the structural plateau of central Sinai, mountainous and hilly areas of North Sinai (Mobile Belt), the Gulf of Suez coastal plain, and the conspicuous unit of northern Sinai (Fig. 1c).

\section{Methods and data}

Eight thematic maps (rainfall amount, net groundwater recharge, lithology, lineament density, terrain slope, drainage density, depth to water, and water quality) were integrated as input layers for the WSPM to perform the groundwater potentiality mapping. Ground truthing had been performed on the lithologic units, depth to water and water quality during several field excursions in 20082009 (NARSS, National Authority for Remote Sensing and Space Sciences, 2009: Surface water/groundwater potentialities of the Sinai Peninsula: determining parameters of sustainability using remote sensing and GIS techniques. Unpublished project report, $222 \mathrm{pp}$ ).
The drilled wells, dug wells and springs data of 386 water points (sources) were inventoried, in addition to the compiled data from published and unpublished sources at different locations in Sinai and for different aquifer systems. A digital elevation model (DEM) with 30-m resolution of the study area was generated from the topographic contours and spot heights. These layers were generated in steps (digitization, editing, building topological structure and finally polygonization) in ArcGIS 9.2 Spatial Analyst (ESRI 2007).

Litho-stratigraphic data were collected from Conoco geological maps of Sinai (Conoco 1987) of 1:500,000 scale. Further enhancement for the extraction of lineament data was performed by the interpretation of Enhanced Thematic Mapper Plus (ETM+) satellite imageries (taken in 2003) using ERDAS Imagine 9.3 software (Leica Geosystems GIS and Mapping 2008).

Drainage areas, routing and runoff information were calculated using 30-m DEMs and the soil conservation service curve number (SCS-CN) model which was run inside the WMS 7.1 software (AQUAVEO 2008). One program that has been developed for the automatic delineation of watersheds and stream arcs on a DEM is the Topographic Parameterization (TOPAZ) program (Garbrecht and Martz 1997). A special version of TOPAZ has been created for use within the WMS software platform, which only requires an elevation grid as input and produces a flow direction grid and a flow accumulation grid as outputs. After defining basins with a DEM, the results are converted to drainage coverage for easier data storage and manipulation.

The empirical and physically based (SCS-CN) method for estimation of the rate of surface runoff (Hogarth et al. 2004; Jain et al. 2005; Tyagi et al. 2008) was used. The purpose of using WMS is to calculate the peak flood discharge for various recurrent interval storms of 10 years in the watershed using digital elevation information and weighted curve numbers generated from the existing land use and soils data. Review of the literature reveals that the SCS-CN method (SCS 1956), owing to its simplicity, is widely used for the computation of volume of direct surface runoff for a given rainfall event from small agricultural and urban watersheds. The major elements of the rainfall-runoff processes are embodied in the SCS$\mathrm{CN}$ method, and they are (1) catchment characteristics; (2) precipitation, evaporation, evapotranspiration; and (3) runoff. The SCS-CN method is based on the water balance equation (Mishra and Singh 2003). The method is based on the following three equations:

$$
P=I_{a}+F+Q
$$

$$
\frac{\mathrm{Q}}{\mathrm{P}-\mathrm{I}_{\mathrm{a}}}=\frac{\mathrm{F}}{\mathrm{S}}
$$

$$
\mathrm{I}_{\mathrm{a}}=\lambda \mathrm{S}
$$



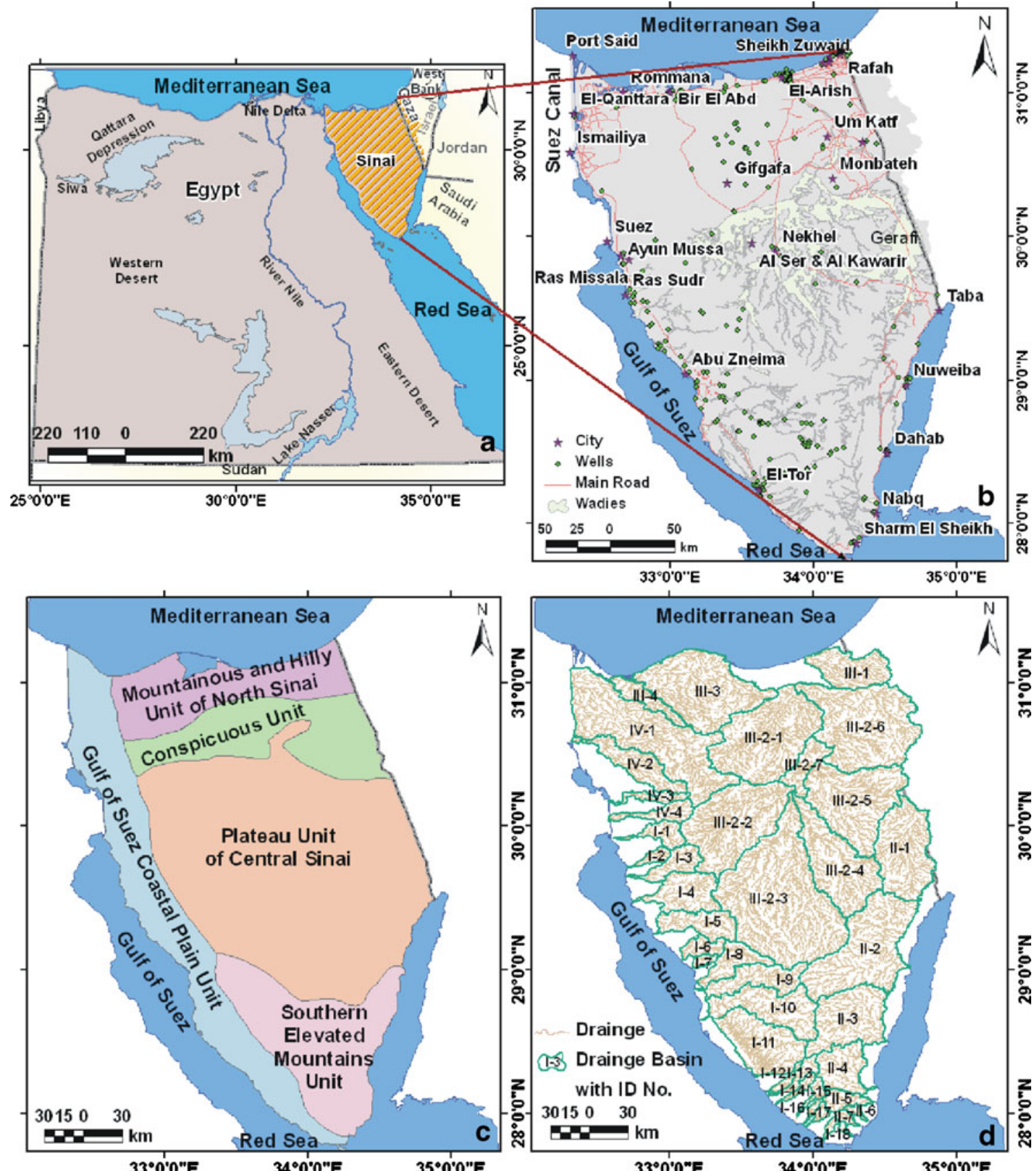

Fig. 1 a Location map, b main physiographic features, $\mathbf{c}$ main geomorphologic features and d drainage net map of study area (Extracted from Landsat ETM + image and GIS techniques)

where $\mathrm{P}=$ total rainfall; $\mathrm{I}_{\mathrm{a}}=$ initial abstraction; $\mathrm{Q}=$ direct runoff; $F=$ cumulative infiltration excluding $\mathrm{I}_{\mathrm{a}} ; \mathrm{S}=$ potential maximum retention after runoff begins; and $\lambda=0.2$ (a standard value). Equation (2) uses the proportionality concept and equates the ratio of the actual direct surface runoff $(\mathrm{Q})$ to potential maximum surface runoff $(\mathrm{P})$ (or total rainfall) to the ratio of the actual retention $(\mathrm{F})$ (or infiltration) to potential maximum retention (S). Coupling of Eq. (1) with Eq. (2) leads to the popular expression of the SCS-CN method:

$\mathrm{Q}=\frac{\left(\mathrm{P}-\mathrm{I}_{\mathrm{a}}\right)^{2}}{\left(\mathrm{P}-\mathrm{I}_{\mathrm{a}}\right)+\mathrm{S}}$
Equation (4) is valid for $\mathrm{P} \geq \mathrm{I}_{\mathrm{a}}, \mathrm{Q}=0$. S is mapped on to curve number $(\mathrm{CN})$ by the following expression:

$\mathrm{S}=\frac{25,400}{\mathrm{CN}}-254$

where $\mathrm{S}$ is in $\mathrm{mm}$ and $\mathrm{CN}$ is non-dimensional. The value of $\mathrm{CN}$ is derived from the tables given in the National Engineering Handbook, section-4 (NEH-4; SCS 1956) for the catchment characteristics such as soil type, land use, hydrologic conditions, and antecedent soil moisture conditions. Although the $\mathrm{CN}$ theoretically varies from 0 to 100 , the practical design values validated by experience lie in the 
Table 1 Hydrographic parameters and WMS outputs for Sinai's drainage basins

\begin{tabular}{|c|c|c|c|c|c|c|}
\hline $\begin{array}{l}\text { Basin ID (see } \\
\text { Fig.1d } \\
\text { for locations) }\end{array}$ & $\begin{array}{l}\text { Wadi (valley) } \\
\text { name }\end{array}$ & $\begin{array}{l}\text { Area } \\
\left(\mathrm{km}^{2}\right)\end{array}$ & $\begin{array}{l}\text { Total } \\
\text { runoff } \\
\left(\mathrm{m}^{3} / \text { year }\right)\end{array}$ & $\begin{array}{l}\text { Surface runoff }\left(\mathrm{m}^{3} /\right. \\
\text { year })\end{array}$ & $\begin{array}{l}\text { Net groundwater } \\
\text { recharge }\left(\mathrm{m}^{3} /\right. \\
\text { year })\end{array}$ & $\begin{array}{l}\text { Time to peak } \\
\text { discharge } \\
(\mathrm{min})\end{array}$ \\
\hline $\mathrm{I}$ & \multicolumn{6}{|c|}{ Gulf of Suez drainage system (southwestern Sinai) } \\
\hline I-1 & El Raha & 440.27 & $5,410,139$ & $3,207,946$ & $2,202,193$ & 1,527 \\
\hline $\mathrm{I}-2$ & Lahata & 192.50 & $1,184,701$ & 658,762 & 525,939 & 1,508 \\
\hline I-3 & Sudr & 601.14 & $4,268,910$ & $2,315,391$ & $1,953,519$ & 1,545 \\
\hline I-4 & Wardan & $1,186.26$ & $7,705,180$ & $4,170,575$ & $3,534,605$ & 1,546 \\
\hline $\mathrm{I}-5$ & Gharandal & 920.32 & $7,202,295$ & $3,925,466$ & $3,276,829$ & 1,540 \\
\hline I-6 & Tayba & 356.43 & $2,444,935$ & $1,342,286$ & $1,102,649$ & 1,501 \\
\hline I-7 & Matala & 119.97 & $1,325,254$ & 822,791 & 502,463 & 1,455 \\
\hline I-8 & Baba & 719.74 & $5,685,007$ & $3,153,539$ & $2,531,468$ & 1,527 \\
\hline I-9 & Sidri & $1,075.16$ & $10,748,927$ & $5,749,065$ & $4,999,862$ & 1,534 \\
\hline $\mathrm{I}-10$ & Feiran & $1,776.29$ & $25,353,243$ & $14,024,982$ & $11,328,261$ & 1,530 \\
\hline I-11 & Alaawag & $1,924.66$ & $24,520,208$ & $13,403,688$ & $11,116,520$ & 1,529 \\
\hline $\mathrm{I}-12$ & Imlaha & 136.83 & 779,984 & 437,229 & 342,755 & 1,430 \\
\hline $\mathrm{I}-13$ & Isla & 276.24 & $1,078,629$ & 570,850 & 507,779 & 1,480 \\
\hline $\mathrm{I}-14$ & Thoman & 149.93 & 543,858 & 282,433 & 261,425 & 1,446 \\
\hline $\mathrm{I}-15$ & El Mahash & 169.16 & 657,802 & 362,561 & 295,241 & 1,450 \\
\hline $\mathrm{I}-16$ & Lethei & 74.46 & 84,136 & 35,437 & 48,699 & 1,449 \\
\hline $\mathrm{I}-17$ & Ghashi & 74.46 & 120,364 & 51,543 & 68,821 & 1,448 \\
\hline $\mathrm{I}-18$ & El At El Gharbi & 79.77 & 123,943 & 52,286 & 71,657 & 1,432 \\
\hline II & \multicolumn{6}{|c|}{ Eastern Sinai drainage system (Gerafi and Gulf of Aqaba) } \\
\hline II-1 & Gerafi & $2,353.66$ & $20,055,825$ & $10,643,109$ & $9,412,716$ & 1,536 \\
\hline II-2 & Watir & $3,522.97$ & $12,720,526$ & $1,394,351$ & $11,326,175$ & 1,543 \\
\hline II-3 & Dahab & $2,071.41$ & $16,563,557$ & $8,620,926$ & $7,942,631$ & 1,529 \\
\hline II-4 & Kid & $1,044.48$ & $7,187,315$ & $3,851,731$ & $3,335,584$ & 1,509 \\
\hline II-5 & Umm Adawi & 364.16 & $1,933,830$ & $1,068,761$ & 865,069 & 1,515 \\
\hline II-6 & Sasir & 83.24 & 128,972 & 50,138 & 78,834 & 1,448 \\
\hline II-7 & El At El Sharki & 107.63 & 174,363 & 75,217 & 99,146 & 1,450 \\
\hline II-8 & Madsus & 39.10 & 49,546 & 23,295 & 26,251 & 1,414 \\
\hline III & \multicolumn{6}{|c|}{ North Sinai drainage system } \\
\hline III-1 & El Kharoba & $1,232.70$ & $15,790,980$ & $8,556,586$ & $7,234,384$ & 1,529 \\
\hline III-2 & El Arish & & & & & \\
\hline III-2-1 & Hamma El Hasana & $3,590.29$ & $28,578,308$ & $16,234,425$ & $12,343,883$ & 1,536 \\
\hline III-2-2 & El Bruk & $3,299.23$ & $26,653,440$ & $14,304,144$ & $12,349,296$ & 1,535 \\
\hline III-2-3 & Yarqa Abu Taryfya & $6,345.60$ & $66,788,359$ & $42,593,062$ & $24,195,297$ & 2,790 \\
\hline III-2-4 & El Fetahy El Aqaba & $2,544.64$ & $25,474,092$ & $14,405,379$ & $11,068,713$ & 1,527 \\
\hline III-2-5 & Geraia & $3,083.58$ & $28,723,209$ & $16,066,820$ & $12,656,389$ & 1,530 \\
\hline III-2-6 & Heridien & $3,905.03$ & $26,569,987$ & $14,792,676$ & $11,777,311$ & 1,542 \\
\hline III-2-7 & $\begin{array}{l}\text { Central Wadi El } \\
\text { Arish }\end{array}$ & 613.32 & $5,558,633$ & $3,098,567$ & $2,460,066$ & 1,535 \\
\hline III-3 & Bardawil sector & $3,332.33$ & $15,888,333$ & $9,309,031$ & $6,579,302$ & 2,832 \\
\hline III-4 & East Bardawil Sector & 583.85 & $3,537,143$ & $1,894,991$ & $1,642,252$ & 1,541 \\
\hline IV & \multicolumn{6}{|c|}{ East of Suez Canal drainage system (northwestern Sinai) } \\
\hline IV-1 & Salam & $4,453.93$ & $32,131,868$ & $20,442,217$ & $11,689,641$ & 3,483 \\
\hline IVI-2 & Umm Khashieb & $1,082.41$ & $8,641,240$ & $4,888,073$ & $3,753,167$ & 1,535 \\
\hline IV-3 & El Giddi & 276.98 & $1,803,290$ & 955,100 & 848,190 & 1,538 \\
\hline IV- 4 & El Hagg & 482.29 & $4,321,224$ & $2,526,852$ & $1,794,372$ & 1,525 \\
\hline
\end{tabular}

range of 40-98 (Mishra and Singh 2004a). The higher the CN value, the greater is the runoff potential of the watershed, and vice versa.

The SCS-CN method is also construed as an infiltration loss model (Chen 1982; Ponce and Hawkins 1996). Hjelmfelt (1980) developed a SCS-CN based infiltration model comparable to the theoretical model of Holtan (1961) infiltration equation (De Roo 2000). Introducing a term for the steady-state infiltration rate, Mishra and Singh (2004b) expressed the SCS-CN infiltration model in the form of the Horton (1938) equation. The curve number is based on the area's hydrologic soil group, land use, treatment and hydrologic condition. Subsequently, a WSPM was constructed using the prepared multi-layer GIS, to classify the study area into five gradational groundwater potential areas. The overall flowchart of methodology is given in Fig. 2.

\section{Results and discussion}

The groundwater potentiality mapping could be achieved through investigation of the sources of water (rainfall and runoff) and the lithologic, structural or geomorphologic factors controlling its occurrence. Accordingly, factors controlling groundwater storage are different in space and time. Factors include: (1) rainfall as a source of water, (2) net groundwater recharge, which is calculated from the basin hydrographs by the SCS method within the WMS software platform, (3) rock types or lithology, which 


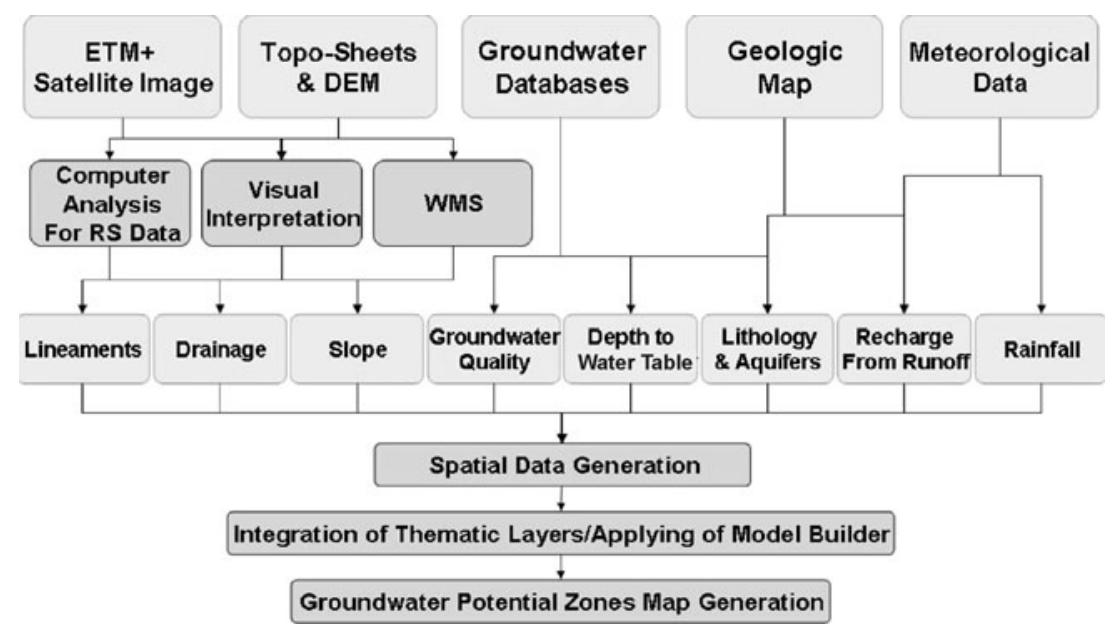

Fig. 2 Flow chart of the methodology used for the study

determine the soil and exposed rocks' infiltration capabilities and govern the flow and storage of water among them, (4) rock fractures or lineaments, which enhance significantly the permeability by inducing secondary porosity and hence permit surface water to percolate easily to recharge the groundwater, (5) terrain slope (or topography), which controls the water flow energy, (6) drainage density, which has a role in the distribution of runoff and determining the level of infiltration, (7) depth to groundwater, which reflects the accessibility of water, and (8) groundwater quality, which influences the usability. The general necessary factors for the success of groundwater potentiality mapping, which also justify the GIS-based WSPM, are the observed groundwater conditions, i.e. the depth to water table and groundwater quality of the already drilled wells or springs. Therefore, the influencing factors on groundwater storage and recharge by rainfall and surface water (runoff) were identified and digitally mapped as thematic layers. The integration of these factors in the GIS multilayer system within the ArcGIS 9.2 software platform enabled the WSPM to be performed, and a groundwater potentiality map was produced with five classes, ranging from very high to very low potentiality to groundwater occurrence.

Accordingly, it is obvious that the current study involves using the largest number of influencing factors or layers for groundwater-potentiality mapping in the Sinai Peninsula for the first time. In this respect, it should be taken into account that these factors are geographically dependant and spatially variable from one area to another. For example, in areas of flat topography, like that of the northern Sinai coastal alluvial plains, slopes are different from those of the karsts and mountainous landforms existing in central and southern Sinai. These land forms must be involved as influencing factors. The infiltration capabilities of karstified formations, i.e. Rizan Aneiza, Matulla and Thebes group, were taken into consideration (Table 2).

The integration of these factors in a systematic procedure will result in a precise groundwater potential map with a number of categories. From this point of view,
RS can contribute to identifying all these factors, but at different levels. For example, rock fractures can be totally extracted from satellite images, while drainage and lithology can be obtained from topographic and geologic maps, but could be enhanced from satellite images. Moreover, not all of these factors have the same degree of influence on groundwater storage, but different levels of effect exist among them. Some of them may significantly contribute in groundwater storage, but some others may act to a limited level. For example, sporadic rainfall and surface runoff are principal efficient factors, but the drainage density or slope are not so.

\section{Rainfall factor}

The regions with high rainfall rates are comparatively water-rich areas, whether the water is surface water or groundwater. However, the total annual rainfall, in general, does not exceed $200 \mathrm{~mm}$; this maximum value occurs in the extreme north at Rafah and El Arish. The minimum annual rainfall value is about $20 \mathrm{~mm}$ in the extreme south at Ras Mohammed, but it reaches to 50$150 \mathrm{~mm}$ in the central-southern region of the mountainous terrains. It is worth mentioning that another arid region occurs in the central region, which is known as the plateaux area, where the annual rainfall does not exceed $30 \mathrm{~mm}$; this restricts, to a significant level, the long-term agricultural development.

In this regard, the geographic distribution of rainfall amount in Sinai was analyzed applying the isohyets method. Data were adopted from the available records of published and unpublished sources (NSG, North Sinai Governorate, 2006: Environmental assessment of North Sinai, Cooperation project between Egypt and Danish Governments. Unpublished, 322 pp). The resulting map presents five major classes. The five classes of rainfall in this study were discriminated into ranges as follows: $<30$, 31-40, 41-50, 51-60, > $60 \mathrm{~mm} /$ year (Fig. 3a). The map shows that the elevated areas receive much more water than the lowland areas. For example, the annual rainfall reaches $70 \mathrm{~mm}$ on some mountainous peaks, while it does 
Table 2 Major exposed rocks in Sinai according to their infiltration capabilities and groundwater potentiality

\begin{tabular}{|c|c|c|c|}
\hline Major lithologic groups & $\begin{array}{l}\text { Soil hydrologic } \\
\text { group }\end{array}$ & $\begin{array}{l}\text { Infiltration rate } \\
\text { (mm/hour) }\end{array}$ & $\begin{array}{l}\text { Groundwater } \\
\text { potentiality }\end{array}$ \\
\hline $\begin{array}{l}\text { Nile silt, sand dunes, undifferentiated Quaternary deposits, } \\
\text { stabilized sandstone, wadi deposits, G. El-Ahmar Fm, } \\
\text { Naqus Fm. }\end{array}$ & A & High infiltration $>7.62$ & $\begin{array}{l}\text { High to very } \\
\text { high }\end{array}$ \\
\hline $\begin{array}{l}\text { Risan Aneisa Fm., Cairo-Suez Hgul Fm., Safa, } \\
\text { Abu Aggag Fm., Duwi Fm., Lake Nasser, } \\
\text { Hammamat clastics, lower to middle Miocene } \\
\text { deposits, Umm Mahara and Ranga Fm., } \\
\text { calc-alkaline granitic rocks-tectonized }\end{array}$ & $\mathrm{B}$ & Moderate infiltration $3.81-7.62$ & Moderate \\
\hline $\begin{array}{l}\text { Matulla Fm., undifferentiated Plio-Pleistocene deposits, } \\
\text { Pliocene deposits, Gharandal Group, metasediments, } \\
\text { Abou Durba Fm., Qiseib Fm. }\end{array}$ & $\mathrm{C}$ & Low infiltration $1.27-3.81$ & Low \\
\hline $\begin{array}{l}\text { Sabkhas deposits, medium-to-high-grade metamorphic rocks, } \\
\text { undifferentiated Thebes Group, Mokattam Group, Samalut Fm., } \\
\text { Egma Fm., Esna Fm., Sudr Fm., Masajid Fm., Egma Fm., } \\
\text { Katherina volcanics, Tertiary alkali olivine basalts, } \\
\text { grey granite or older granite, mostly leucocratic } \\
\text { medium-to-high grade metamorphic rocks, intrusive } \\
\text { metagabbro to metadiorite, } \\
\text { Ras Malaab Group, ring complexes, intermediate to } \\
\text { acid metavolcanics and metapyroclastics, gneiss and } \\
\text { magmatic gneiss, gabbroic rocks, pink granite, } \\
\text { Quseir Fm., Trachyte plugs and sheets }\end{array}$ & $\mathrm{D}$ & Very low infiltration $<1.27$ & Very low \\
\hline
\end{tabular}

not exceed $40-50 \mathrm{~mm}$ in the coastal regions of Sinai (Fig. 3a). This layer was assigned a weight of 30 in the WSPM.

\section{Net groundwater recharge from runoff water}

Surface water resulting from sporadic rainfall events represents one of the major sources for groundwater recharge. Most of the rainfall water recharges the shallow aquifers in northern Sinai such as the delta of Wadi El Arish and El-Qaa flood-plain, while such aquifers are absent in southern Sinai. Although groundwater in most of the shallow aquifers is renewable, only $10-20 \%$ of the deep aquifers are renewable by rainfall and flash floods. The total groundwater abstraction is only 0.09 billion $\left(10^{9}\right) \mathrm{m}^{3} /$ year (Abu Rayan et al. 2001). Four major
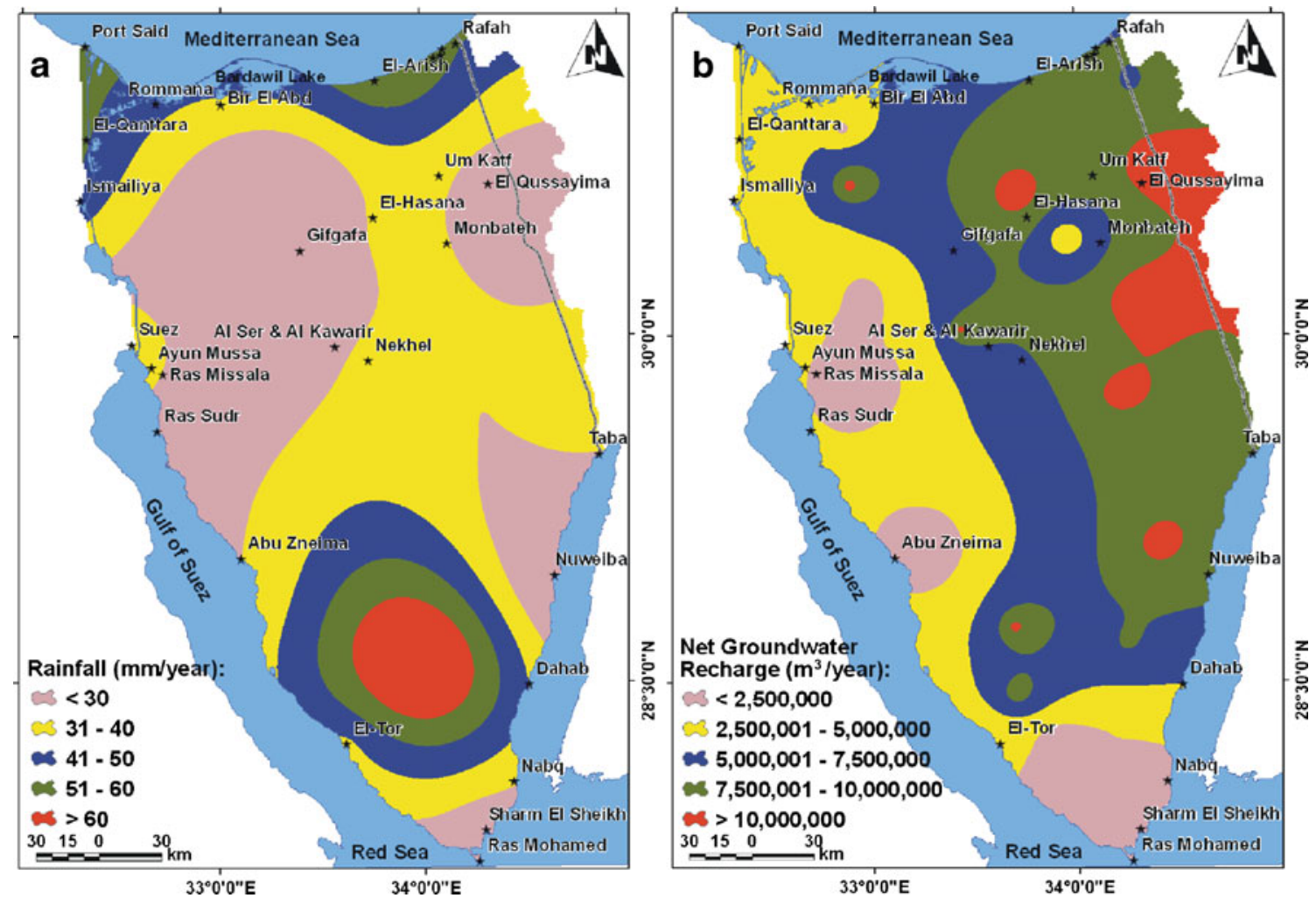

Fig. 3 a Rainfall potentiality classes and $\mathbf{b}$ net groundwater recharge potentiality classes 
drainage systems dissect Sinai landforms in a radial form (Table 1; Fig. 1d), which include the Gulf of Suez (southwestern Sinai), eastern Sinai (Gerafi and the Gulf of Aqaba), North Sinai, and east of the Suez Canal (northwestern Sinai). Most of these wadies originate from the mountainous territories with short lengths, deep and steep slopes, except Wadi El Arish, which is wider and shallower, especially at its northern reaches. Wadi El Arish $\left(20,837 \mathrm{~km}^{2}\right)$ collects a considerable amount of water from a very wide catchment in central Sinai with a total runoff of $208,346,028 \mathrm{~m}^{3} /$ year (Table 1). The recharge-to-groundwater portion of this total runoff volume (base flow) is $86,850,955 \mathrm{~m}^{3} /$ year, whereas the remaining runoff volume, which is lost by either evaporation or debouching into the Mediterranean Sea (overland flow) is $121,495,073 \mathrm{~m}^{3} /$ year (Table 1 ).

Comparatively, the eastern drainage system (Gerafi and Gulf of Aqaba) produces a total runoff water of $58,813,934 \mathrm{~m}^{3} /$ year, which is divided into $25,728,228$ $\mathrm{m}^{3} /$ year overland flow and $33,086,406 \mathrm{~m}^{3} /$ year base flow. The Gulf of Suez drainage system produces 99,237,515 $\mathrm{m}^{3} /$ year as a total runoff volume, where $54,566,830 \mathrm{~m}^{3} /$ year represents the overland flow and 44,670,685 $\mathrm{m}^{3} /$ year is going to feed the groundwater.

Consequently, the watersheds of Sinai were analyzed for their runoff and groundwater recharge possibilities, as illustrated in Table 1. The WMS simulated the hydrograph for each drainage basin in Sinai and these parameters are calculated from the hydrographic separation including total runoff volume $\left(\mathrm{m}^{3} /\right.$ year), surface runoff volume $\left(\mathrm{m}^{3} /\right.$ year) (overland flow or area occurring above the inflection points of the hydrographs) and, net groundwater recharge volume $\left(\mathrm{m}^{3} /\right.$ year; base flow or area occurring under the inflection points of the hydrographs). However, this factor is one of the most influencing parameters on groundwater potentiality mapping; hence, it was given a weight of 20. Similarly, the output map was discriminated into five major classes as; $<2.5,2.5-5,5-7.5,7.5-10,>10$ million $\mathrm{m}^{3} /$ year (Fig. 3b). However, the rainfall and groundwater recharge maps reflect each other, where the higher the rainfall amount, the higher the groundwater recharge possibility, and vice versa (Fig. 3a and b).

\section{Lithology factor}

Knowledge of litho-stratigraphy of a region is essential to understand the nature and distribution of their water bearing properties (Fetter 1994). The litho-stratigraphic units of the area were generated from the Conoco (1987) geological map of the Sinai of scale 1:500,000. The different lithologies have been traced and digitized as polygons in a layer and then edited and generated as a thematic map in ArcGIS 9.2 software (ESRI 2007). Further modifications of this map were performed by remote sensing. More certainly, the use of SPOT 4 (pixel size $10 \mathrm{~m}$ ) and Landsat 7 ETM + satellite images (pixel size $30 \mathrm{~m}$ ) were helpful in this regard, thus boundaries of many exposed rock formations were precisely corrected. The image processing was performed by using ERDAS
Imagine 9.3 software. Band combination was a useful application and was carried out to reach the most distinguished observations on satellite images; therefore, the order of bands 7, 4 and 2 were selected to identify clearly the textural and pattern attributes of the terrain surface.

In addition, many other digital enhancements were used such as filtering and contrasting; thus, visual tracings of many lithological units and their boundaries were plotted. Consequently, an empirical classification of the lithologic formations according to their infiltration capabilities or signatures was carried out; thus, a map with four classes was produced to reveal rock formations of similar infiltration properties or lithologic groups $\mathrm{A}, \mathrm{B}, \mathrm{C}$ and $\mathrm{D}$ depending on intensive previous investigations or previous work (NARSS 2009 and references therein) in addition to the registered values of the curve number method (SCS 1956; Table 2). Here, the most important factor is the content of clay in different lithologies, especially in bare soils and sedimentary rocks, because it controls water infiltration and reduces the permeability. Also, the rock hardness was accounted in the classification since hard rocks are often brittle and result in fracturing systems, which in turn enhances rock permeability and porosity. In the obtained classification, rock formations of similar hydrologic properties were embedded in one map (Fig. 4a). The classified map with four classes was used instead of the five classes, as the soil/exposed rocks' infiltration class $B$ includes both high and moderate infiltration capabilities. This layer was assigned a weight of 20 in the GIS-based WSPM.

\section{Lineament density factor}

Lineament analysis for groundwater exploration has considerable importance, where the joints and fractures serve as conduits for movement of groundwater and have water-holding capacity. Fractures in rocks increase their secondary permeability and porosity, and thus accelerate vertical water percolation to recharge the aquifers. For this reason, identifying fractures in rocks is considered as a major factor in identifying groundwater potential areas. The first detailed structural lineation map constructed for the sake of groundwater exploration was introduced by ElShazly et al. (1980).

It is not practical to map lineaments solely on the basis of satellite data without a thorough knowledge of the structural conditions in an area. For extraction of lineaments, the procedure of Moore and Waltz (1986) has been followed, where lineaments derived from satellite ETM + data (acquired in 2003) have been carefully matched with the previously mapped structural features and a good degree of correlation between the two has been found.

Accordingly, the detected linear features of all sizes and orientations, regardless of their origin, were extracted and then plotted on a map. Nevertheless, erroneous plotting of some lineaments exists, because not all 

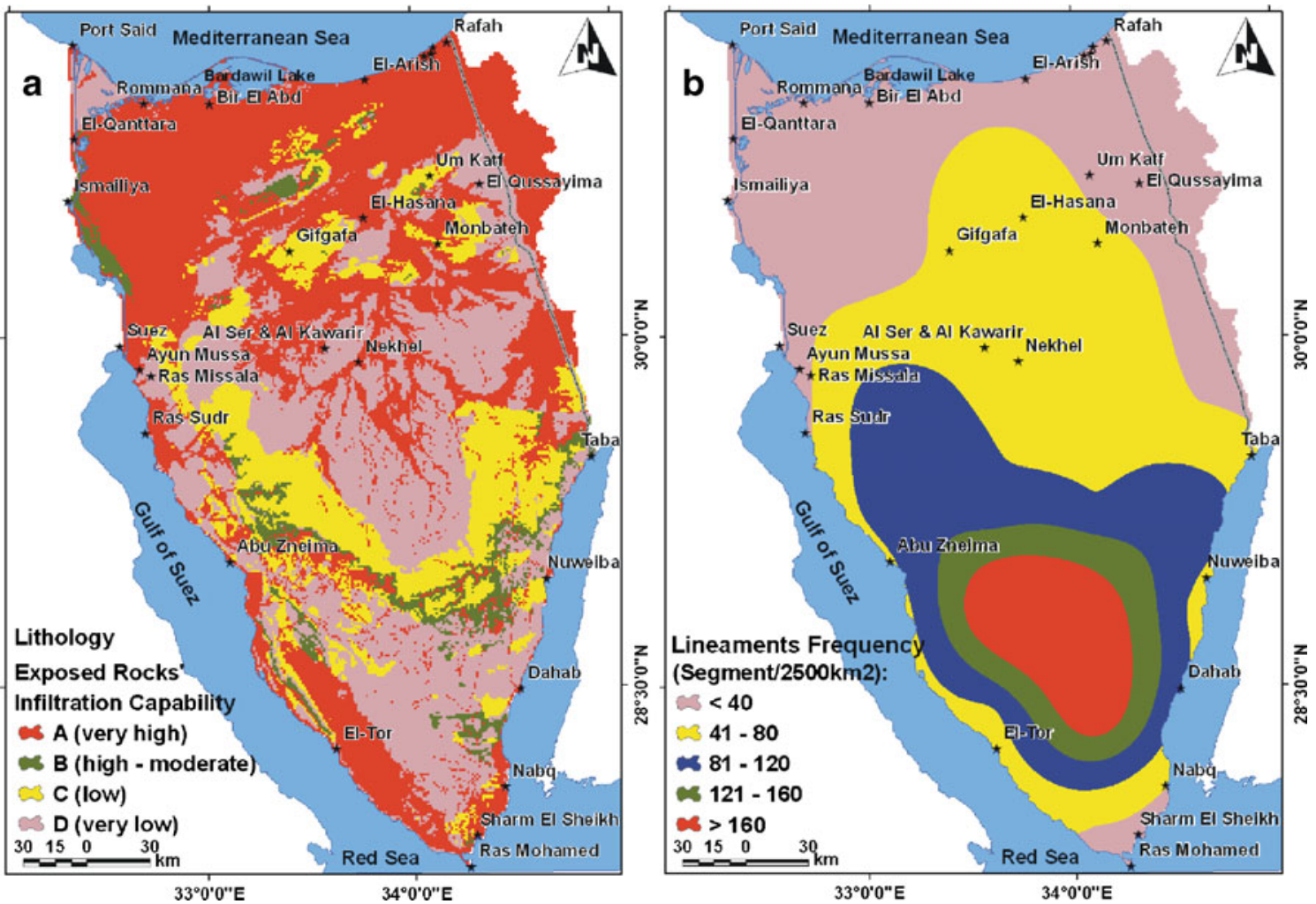

Fig. 4 a Infiltration of lithologic unit's potentiality classes and $\mathbf{b}$ lineaments density classes

detected linear features are geologically related. However, to avoid this error, all linear objects (e.g. roads, pipelines and terraces) appearing on the digital topographic maps were overlapped on the produced lineament map. This enabled elimination of all non-geologic linear features plotted in the lineament map. In this regard, all obtained studies pointed out that the existing lineaments on the satellite images are often attributed to fracture systems (Degnan and Clark 2002), in which the higher the density of lineaments, the higher the permeability and porosity in rocks and vice versa. The resulting lineament map shows only the spatial distribution and dimensions of linear features. Consequently, the density (i.e. concentration) cannot be directly figured out. For this purpose a systematic approach, which had been adopted by a number of steps done in previous studies (Teeuw 1995; Sener et al. 2005), was performed to harmonize the spatial distribution of lineaments in density zones. The lineament density was expressed by classifying the area into specific frames $(50 \mathrm{~km} \times 50 \mathrm{~km})$, and thus the number of lineaments in each grid cell was automatically counted, and the resulted value was plotted in the mid-point of each cell, producing a grid map with nodes and attribute values. From the grid map, contour lines could be drawn to reflect the lineament density. The resulting lineament density map was divided into five classes with each class referring to a range of lineament density, which represents the number of lineaments per unit area $\left(2,500 \mathrm{~km}^{2}\right)$. The five classes in this study were as follows: < 40, 41-80, 81-120, $121-160,>160$ lineament $/ 2,500 \mathrm{~km}^{2}$ (Fig. 4b). The highest lineament density classes (121-160 and >160) occurred within the fractured basement territory of southern Sinai, whereas the density decreases away from this territory towards north and south (Fig. 4b). This layer was given a weight of 10 in the WSPM.

\section{Slope factor}

Slope is the change in elevation of a surface and it is expressed as a percentage or in degrees. A value of $0 \%$ represents a slope of $0^{\circ}$ while a value of $100 \%$ represents a slope of $45^{\circ}$. The relationship between percentage and degrees as represented on this case is non-linear. In the present study, the slope map was generated from the DEM. Slope plays a very significant role in determining infiltration vs. runoff. Infiltration is inversely proportional to slope, i.e. the water infiltration decreases with the increase in slope steepness. The slope map of the study area is presented in Fig. 5a.

In many studies related to groundwater flow and storage, the slope is often ignored; especially in areas with less mountainous terrains. However, slope helps control the likelihood that the surface water will run off or remain on the surface in one area long enough to infiltrate (long residence time). Typically, steeper slopes signify higher groundwater velocity. Slope as a factor in groundwater recharge has a two-fold influence. In order to diagnose this influence, a comparative analysis was undertaken between mountainous areas of southern Sinai (moderate to steep slopes) and relatively 


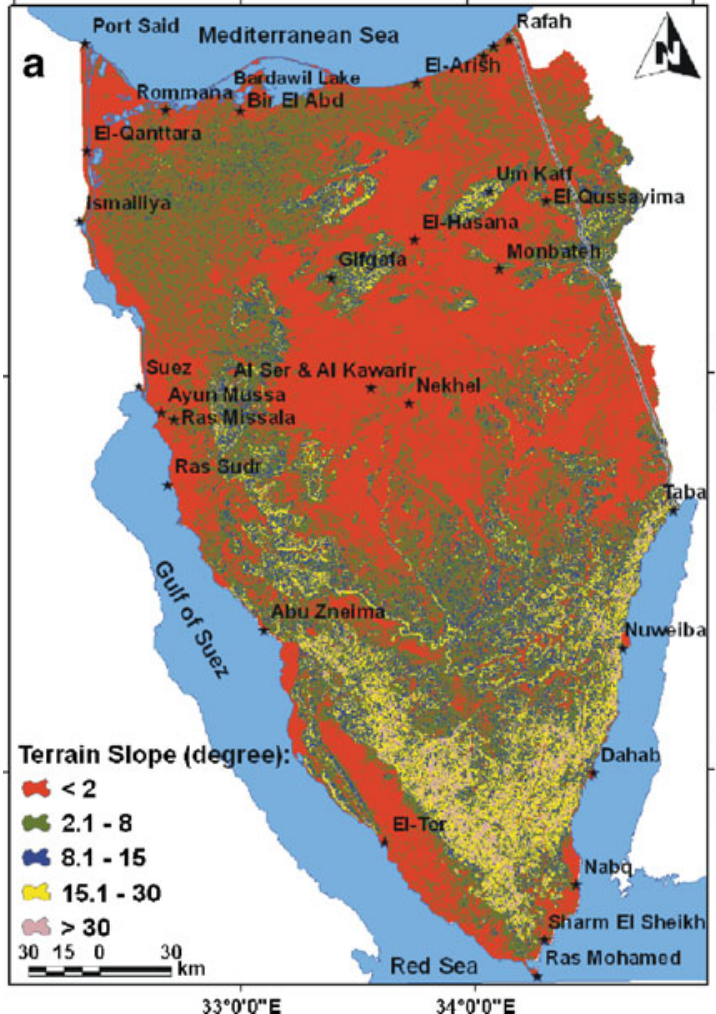

Fig. 5 a Slope classification classes and $\mathbf{b}$ drainage density classes

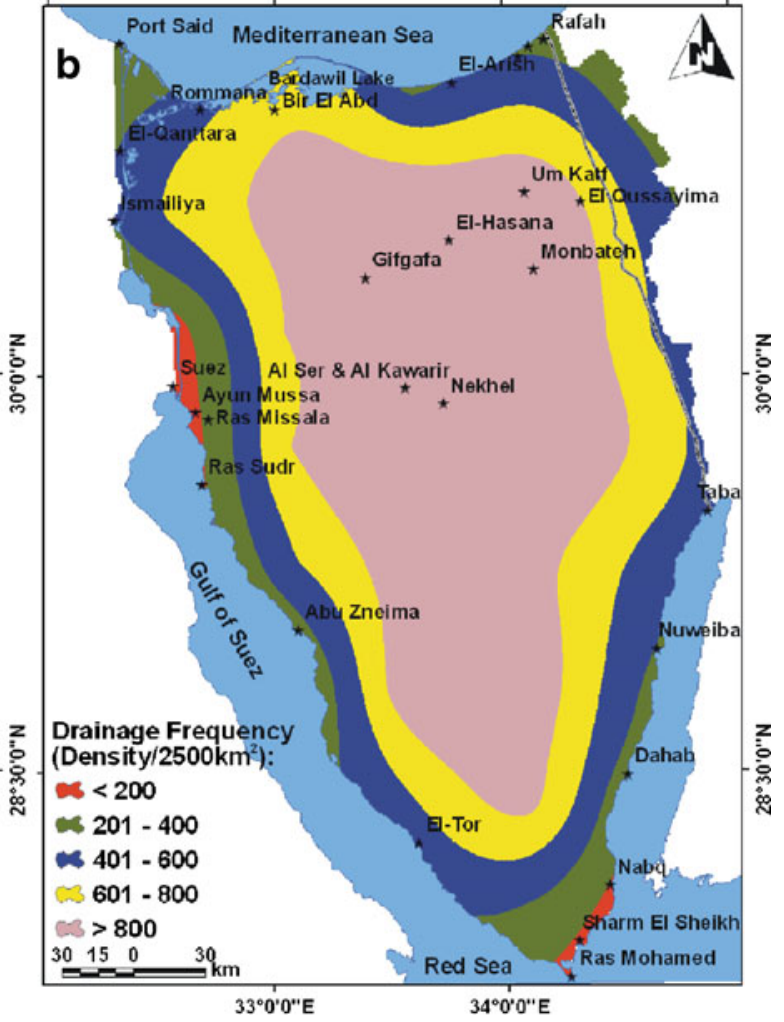

classified slopes and their description according to SOTER Model (Van Engelen and Wen 1995 and the references therein). This layer was assigned a weight of 5 in the WSPM. regions, there is a higher flow of energy and water is often diverted into channels (i.e. runoff), minimizing the overland flow. This in turn will minimize the degree of groundwater recharge (Doll et al. 2002), because water flow will be restricted to streams, feeding groundwater only from the interflow process. While in relatively gentle sloping terrains, the overland flow occurs to cover large spatial distribution and the degree of recharge will be much more. Slope (topography) influences soil development and therefore has an effect on attenuation. In mountainous regions, alluvial deposits are always rare, which is due to the slopping surface that accelerates the erosion processes, whereas in flat terrains, thick fine sediments often occur, which may retard to a certain limit, the recharge rate. The slope classification map comprises five classes for Sinai terrain slope, where the maximum slope influencing terrain is $60 \%$. Table 3 shows the

Table 3 Classification of slope degree as adopted from SOTER Model

\begin{tabular}{lll}
\hline Slope (degrees) & Description & Groundwater potentiality \\
\hline$<2$ & Flat & Very high \\
$2-8$ & Undulating & High \\
$8-15$ & Rolling & Moderate \\
$15-30$ & Moderately steep & Low \\
$30-60$ & Steep & Very low \\
\hline
\end{tabular}

\section{Drainage density factor}

According to the general morphologic characteristics of the Sinai Peninsula and geographic features (Fig. 1b and c), the prevailing drainage pattern is the radial and dendritic type but locally exhibits structural control of topography and geology, where all wadies are debouching from the high mountainous areas towards Sinai's three coasts. A surface drainage map has been prepared from the DEM of $30 \mathrm{~m}$ resolution, toposheets at 1:250,000 scale and satellite ETM + data (Fig. 1d). The hydrologic drainage network exhibits an ideal radial system that is more complete than any similar drainage system in Egypt. The Sinai drainage system is of external type (drains to sea) and drains towards the Mediterranean Sea, Gulf of Suez and Gulf of Aqaba. Another interesting morphological feature, which indicates the complexity of Sinai hydrological characteristics, is the Tina Plain located at the northwestern corner of the Peninsula. This plain is a part of the Nile Delta and was formed by an old tributary of the Nile (Pelusium branch). To the north of the northern mountain terrains of Sinai, extending from Suez to Abu Augeila, several dry wadies run in an internal manner into the desert, i.e. Wadi El-Hag and Wadi ElHassana. To the northwest of the head of the Gulf of 
Aqaba at El-Kuntilla, there is a spot containing tributaries of Wadi El-Girafi, which is a part of Wadi Araba, which in turn, debouch to the Dead Sea in Palestine-Israel. The drainage system here is entirely an internal type. However, this is the only remarkable spot in Sinai that has an internal drainage type.

The rate of surface-water recharge to groundwater is governed also by the characterization of drainage systems. Therefore, the drainage density has often been a part of similar studies, and is almost embedded with lineaments, as they control the drainage lines in some parts of the watersheds, to propose groundwater potential areas-i.e. in studies performed by Edet et al. (1998) and Robinson et al. (1999). Drainage density, which is defined as the unit length of stream channel per unit area, has been shown to vary between regions due to different climatic regimes, natural landscape characteristics, and land-use impacts (Tucker and Bras 1998). According to the common geomorphologic concept, the denser the drainage, the less recharge rate and vice versa. However, one of the major approaches to express drainage density involves the number of drainage segments per unit area, which is also called "drainage frequency". The resulting drainage map was also assigned to five classes by following the same approach used in preparation of the lineament density map. Therefore, each class represents a range in the number of drainage segments (i.e. reaches) per unit area of $2,500 \mathrm{~km}^{2}$. These classes were ordered as: $<200,201-$ $400,401-600,601-800,>800$ segment $/ 2,500 \mathrm{~km}^{2}$ and they were digitized in a map to represent a number of thematic GIS layers (Fig. 5b). This layer was assigned a weight of 5 in the WSPM (Table 4).

\section{Depth to water-table factor}

The depth to water level mostly depends upon the hydrogeological conditions of the area as well as topography, rainfall pattern, etc. Groundwater in Sinai is mainly encountered in five different water-bearing formations: the shallow Quaternary aquifers in northern Sinai (depth to water table, WD, is $<15 \mathrm{~m}$ below ground level, bgl) ; the valley aquifers (WD is $16-45 \mathrm{mbgl}$ ); the Miocene sandstone aquifers along the Gulf of Suez coast and other areas (WD is 16-45 mbgl); the deep aquifers of Lower Cretaceous and older contiguous sandstones in western and midland areas (WD is $>61 \mathrm{mbgl}$ ), and the crystalline basement rocks in southern Sinai (WD is 16$45 \mathrm{mbgl}$ ). The shallow aquifers in the northern coastal part of Sinai are composed of stabilized sand dunes that hold the seasonal rainfall, which helps to fix these dunes. The aquifers in the valleys of Sinai are recharged from rainfall and especially from heavy storms. On the other hand, the Nubian Sandstone Aquifer and older aquifers extend laterally in the subsurface for approximately $10,000 \mathrm{~km}$ from the margins of the crystalline massif of central Sinai to the Gulf of Suez in the west, where the undulating topography is seen. The recharge is believed to have taken place through the sandstone outcrops at the northern flanks of the Precambrian basement complex in central
Sinai and to a lesser extent through erosion windows in Sinai and Negev (Issar et al. 1972).

The total number of 386 water points (drilled wells, hand-dug wells and springs) were compiled and justified as a thematic layer for the GIS manipulation. The depth to water-table increases in Cretaceous and older aquifers located in central and eastern Sinai, whereas it decreases due north and south for the Quaternary aquifers (Fig. 6a). Although the Lower Cretaceous aquifer is the most prospective aquifer in Sinai, it is not yet precisely evaluated. Spatially distributed areas of good groundwater quality suitable for various types of development are not identified. However, this factor of potentiality assessment determines the economies of consumption and abstraction. This layer was assigned a weight of 5 in the WSPM (Table 4).

\section{Groundwater quality factor}

The data for total dissolved solids (TDS) in water extracted from the groundwater points, which were classified by province and geologic units, showed that the southern elevated mountainous unit generally has the best groundwater quality $(<1,500 \mathrm{ppm})$, whereas the Gulf of Suez coastal plain unit has the worst $(>4,500 \mathrm{ppm}$; Fig. 6b). Among all the geologic units, the crystalline rocks, the Middle Cretaceous sequence, and the Quaternary deposits yield water with the lowest TDS (Fig. 6b). The mean TDS value of groundwater from all water points in Sinai for which data were available is $2,800 \mathrm{ppm}$. Of all the geologic units, the highest mean yield $\left(200 \mathrm{~m}^{3} /\right.$ day $)$ was from the Quaternary aquifer in the vicinity of El Arish in the north and in the El Qaa plain along the southwest coast. The aquifers in those areas are subject to salt-water intrusion, where the TDS in this water ranges from 2,000 to $9,000 \mathrm{ppm}$, which can be treated to reach a suitable salinity level for irrigation of certain crops. Drilling of production wells in the degraded groundwater quality areas for municipal supply and coastal rehabilitation, using desalination techniques, has become common practice in the famous recreational town of Sharm El Sheikh (Fig. 6b). The groundwater quality layer was given a weight of 5 in the WSPM (Table 4).

\section{WSPM implementation and validation}

The five WSPM classes, for each determining factor discussed in the previous sections, were ranked according to their magnitude of contribution to groundwater entrapment, thus they were categorized from very high to very low contribution, and the same classes were used in the groundwater potentiality mapping (Table 4; Fig. 7). The philosophy of data manipulation implies integrating all factors as thematic layers in the WSPM. Accordingly, an output map will be obtained with a number of classes indicating the categories of groundwater potentiality (e.g. very high, high, moderate, etc). However, not all the previously discussed factors have the same magnitude of 
Table 4 Ranks and weights for factors and their influencing classes used for groundwater potentiality mapping:

\begin{tabular}{|c|c|c|c|c|}
\hline Data layer (factor) & Class & Average rank $\left(R_{\mathrm{f}}\right)$ & Weight $\left(W_{\mathrm{f}}\right)$ & Degree of effectiveness $(E)$ \\
\hline \multirow[t]{5}{*}{ Rainfall } & I (very high) & 90 & \multirow[t]{5}{*}{$30 \%(0.3)$} & 27 \\
\hline & II (high) & 70 & & 21 \\
\hline & III (moderate) & 50 & & 15 \\
\hline & IV (low) & 30 & & 9 \\
\hline & $\mathrm{V}$ (very low) & 10 & & 3 \\
\hline Net groundwater & I (very high) & 90 & \multirow{5}{*}{$20 \%(0.2)$} & 18 \\
\hline \multirow[t]{4}{*}{ Recharge from runoff } & II (high) & 70 & & 14 \\
\hline & III (moderate) & 50 & & 10 \\
\hline & IV (low) & 30 & & 6 \\
\hline & $\mathrm{V}$ (very low) & 10 & & 2 \\
\hline \multirow[t]{4}{*}{ Lithology } & I (very high) & 90 & \multirow[t]{4}{*}{$20 \%(0.2)$} & 18 \\
\hline & II-III (high-moderate) & 60 & & 12 \\
\hline & IV (low) & 30 & & 6 \\
\hline & $\mathrm{V}$ (very low) & 10 & & 2 \\
\hline \multirow[t]{5}{*}{ Lineament density } & I (very high) & 90 & \multirow[t]{5}{*}{$10 \%(0.1)$} & 9 \\
\hline & II (high) & 70 & & 7 \\
\hline & III (moderate) & 50 & & 5 \\
\hline & IV (low) & 30 & & 3 \\
\hline & V (very low) & 10 & & 1 \\
\hline \multirow[t]{5}{*}{ Depth to water table } & I (very high) & 90 & \multirow[t]{5}{*}{$5 \%(0.05)$} & 4.5 \\
\hline & II (high) & 70 & & 3.5 \\
\hline & III (moderate) & 50 & & 2.5 \\
\hline & IV (low) & 30 & & 1.5 \\
\hline & $\mathrm{V}$ (very low) & 10 & & 0.5 \\
\hline \multirow[t]{5}{*}{ Groundwater quality } & I (very high) & 90 & \multirow[t]{5}{*}{$5 \%(0.05)$} & 4.5 \\
\hline & II (high) & 70 & & 3.5 \\
\hline & III (moderate) & 50 & & 2.5 \\
\hline & IV (low) & 30 & & 1.5 \\
\hline & $\mathrm{V}$ (very low) & 10 & & 0.5 \\
\hline \multirow[t]{5}{*}{ Drainage density } & I (very high) & 90 & \multirow[t]{5}{*}{$5 \%(0.05)$} & 4.5 \\
\hline & II (high) & 70 & & 3.5 \\
\hline & III (moderate) & 50 & & 2.5 \\
\hline & IV (low) & 30 & & 1.5 \\
\hline & $\mathrm{V}$ (very low) & 10 & & 0.5 \\
\hline \multirow{5}{*}{ Terrain slope } & I (very high) & 90 & \multirow{5}{*}{$5 \%(0.05)$} & 4.5 \\
\hline & II (high) & 70 & & 3.5 \\
\hline & III (moderate) & 50 & & 2.5 \\
\hline & IV (low) & 30 & & 1.5 \\
\hline & $\mathrm{V}$ (very low) & 10 & & 0.5 \\
\hline
\end{tabular}

contribution on groundwater potentiality. For example, the factors of rainfall amount or net groundwater recharge from runoff water are much more effective than lineament density or depth to water table. Also, some factors work negatively while others work positively in groundwater potential.

From this point, the slope and drainage factors, which have two different degrees of influence on groundwater recharge (Horton 1938), were given the least level of contribution and, thus, each factor was assigned a specific weight of effect on groundwater potentiality. The weights and rates were adopted and optimized by the extracted factors from the results of experience or judgments of the authors and the knowledge of experts in the previous similar works on groundwater potentiality mapping (i.e. qualitative methods, for example, Edet et al. 1998; Robinson et al. 1999; Das 2000), in addition to the geostatistical normalization and cross-validation (quantitative methods) within the ArcGIS platform before running the model (Isaaks and Srivastava 1989).

Cross-validation helps in making an informed decision as to which model provides the best predictions. The calculated statistics serve as diagnostics that indicate whether the model and/or its associated parameter values are reasonable. The weights and rates were modified based on the magnitude of relations between each layer range of the WSPM classified layers. Therefore, the integrated factors in this study were given the following weights: rainfall $(30 \%)$, net groundwater recharge by runoff water $(20 \%)$, lithology $(20 \%)$, lineament density $(10 \%)$, drainage density $(5 \%)$, terrain slope $(5 \%)$, depth to water table $(5 \%)$ and groundwater quality (5\%). In addition to the proposed weighting, categorization was applied to each of the five classes among each factor. For this purpose, the classes ranged from I (very high potential) up to $\mathrm{V}$ (very low potential) in terms of their importance with respect to groundwater occurrence or potentiality (Table 4).

Consider $100 \%$ as a maximum value for the rank, thus for the five classes, ranks will be categorized as $100-80,80-60,60-40,40-20$ and $20-0 \%$, respectively. Therefore, the average of ranking for each class will be $90,70,50,30$ and $10 \%$ for classes from I to $\mathrm{V}$, respectively (Table 4). In order to calculate the degree of effectiveness (E) for each factor (input data layer), 

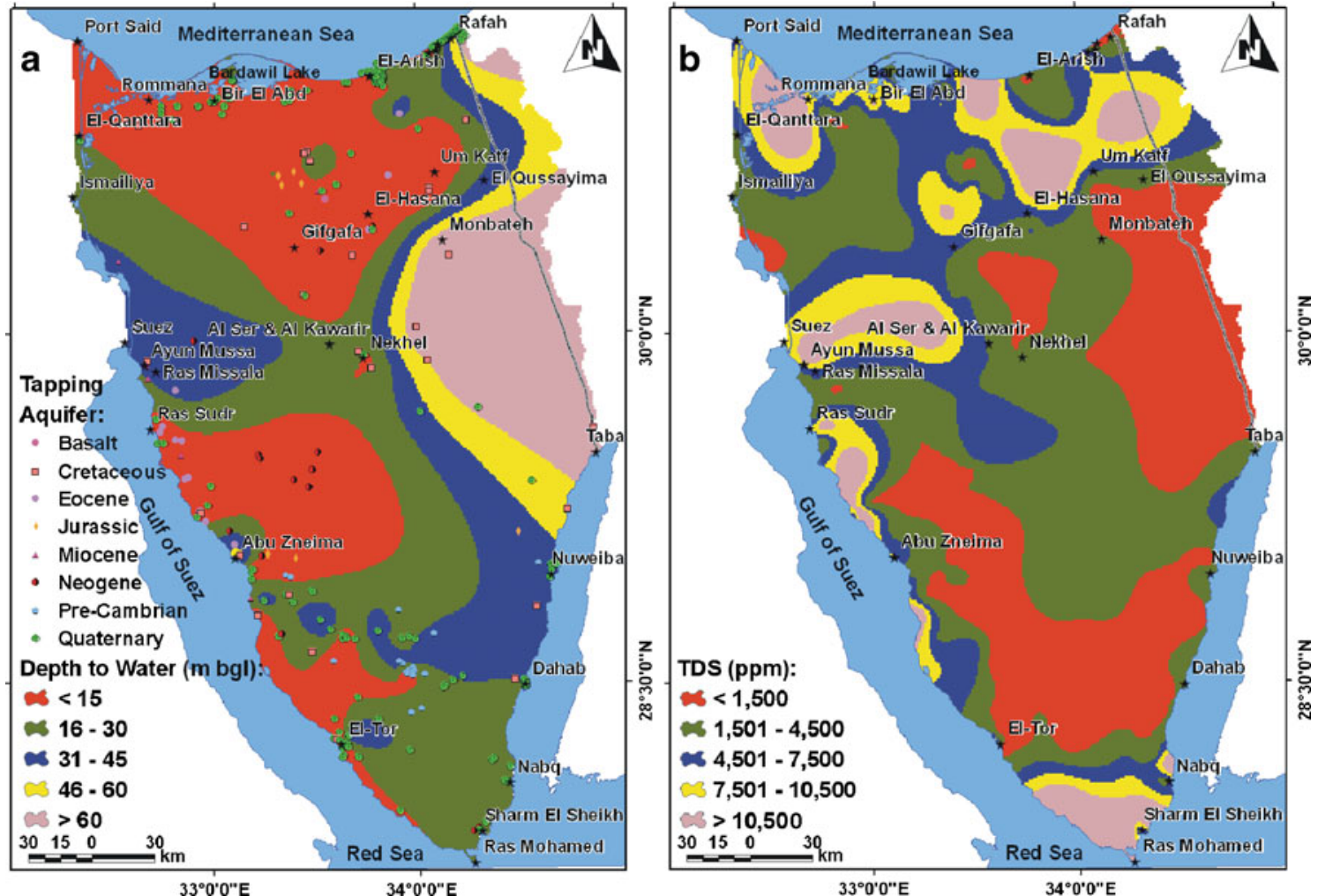

Fig. 6 a Depth to groundwater and $\mathbf{b}$ groundwater total dissolved solids (TDS) classes

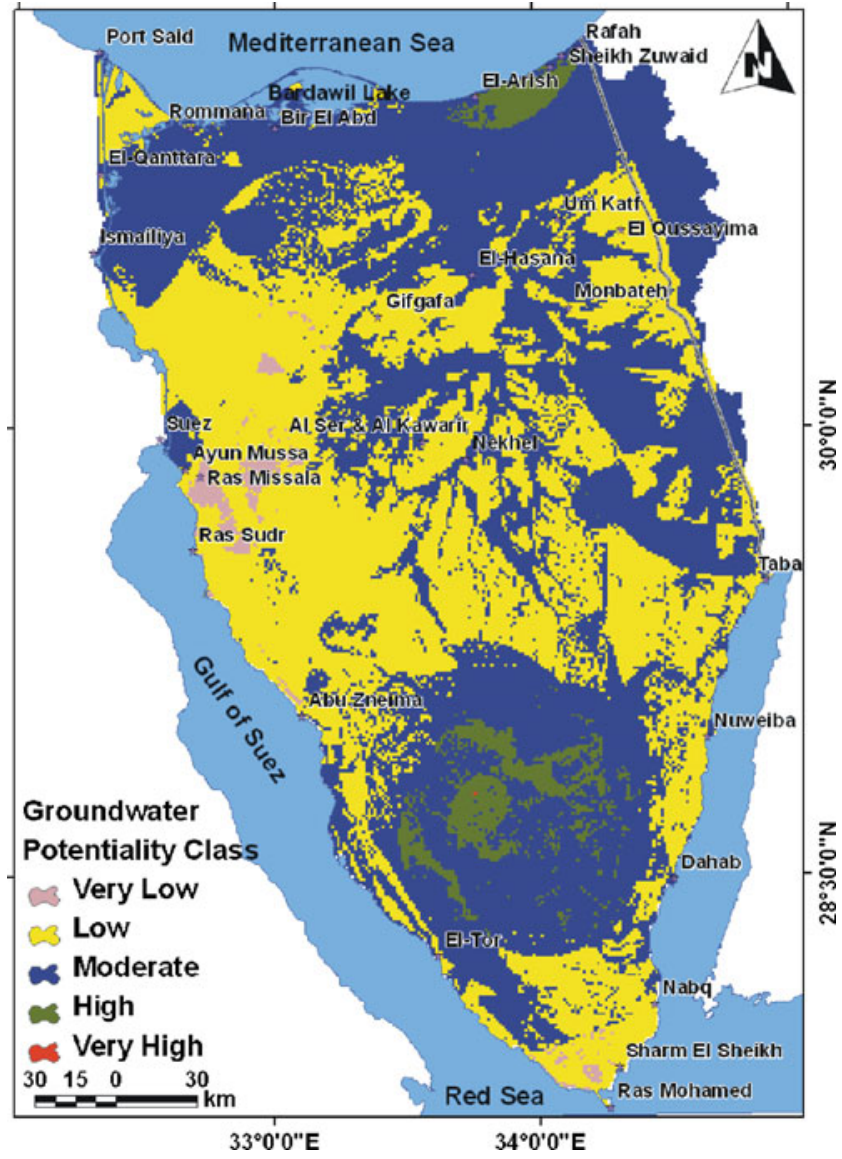

Fig. 7 Groundwater potentiality map of Sinai from the factor weight $\left(\mathrm{W}_{\mathrm{f}}\right)$ and factor rank $\left(\mathrm{R}_{\mathrm{f}}\right)$, the weight was multiplied by the rank $\left(\mathrm{W}_{\mathrm{f}} \times \mathrm{R}_{\mathrm{f}}\right)$. For example, if the weight of rainfall factor equals $30 \%$, and this is multiplied by the average rank of 90, (for class I), the degree of effectiveness will be:

$\mathrm{E}=\mathrm{W} \times \mathrm{R}_{\mathrm{f}}=0.3 \times 90=27$

While for the depth to water-table factor, for example, the degree of effectiveness in class I will be: $90 \times 0.05=4.5$. Following this procedure of data manipulation enables evaluation of the effectiveness of each factor; it also provides a comparative analysis between different input data layers. Therefore, it is obvious from the obtained table of hydrographic parameters (Table 1) that class I in the rainfall factor (i.e. $\mathrm{E}=27$ ) represents the most effective factor with respect to groundwater potentiality, compared to the least influence of class $\mathrm{V}$ (i.e. $\mathrm{E}=0.5$ ) in the terrain slope, drainage density, depth to water table and waterquality factors.

For this purpose, the arithmetic overlay approach built into ArcGIS 9.2 Spatial Analyst Model Builder was adopted for this WSPM. Such an arithmetic overlay process accepts both continuous and discrete grid layers, and the derived data are continuous grid data layer. The resulting map with five major classes of groundwater potentiality was ascribed from very low to very high potentiality. This is attributed as: $<20 \%$ (very low), 21-40\% (low), 41-60\% (moderate), 61-80\% (high) and $>80 \%$ (very high) for the groundwater potentiality (Fig. 7). 
Table 5 Areas of groundwater potentiality classes $\left(\mathrm{km}^{2}\right)$. Total area studied: $63,337.24 \mathrm{~km}^{2}$

\begin{tabular}{llllll}
\hline Potentiality class & Very low & Low & Moderate & High & Very high \\
\hline Area $\left(\mathrm{km}^{2}\right)$ & 682.70 & $27,380.13$ & $33,120.86$ & $2,152.82$ & 0.73 \\
Area $(\%$ of total area of Sinai) & 1.07 & 43.22 & 52.29 & 3.39 & 0.001 \\
\hline
\end{tabular}

However, the output groundwater potentiality map pointed out that the promising localities for groundwater storage are almost located in areas where rainfall is relatively higher and rock fractures are dominant, which often are situated in the elevated region in the mid and southern parts of Sinai (Fig. 7). The regions having very high groundwater potentiality exhibit an area of $0.73 \mathrm{~km}^{2}(0.001 \%$ of the total Sinai area), whereas the regions characterized by very low groundwater potentiality is about $682.70 \mathrm{~km}^{2}(1.07 \%$ of total Sinai area). However, the moderate groundwater potentiality class occupies $52.29 \%$ of the mapped area, while the low potentiality exhibits about $43.22 \%$, indicating the overall moderate groundwater potentialities of the Sinai Peninsula (Table 5).
The output groundwater potentiality map prepared with the WSPM technique (Fig. 7) was checked by matching with the published hydrogeologic map of Egypt (RIGW 1999), and it was observed that the WSPM map has a higher degree of confidence. The high potential groundwater zones of the present work are equivalent to the "local and highly productive aquifers subjected to occasional surface recharge from rainfall, from surface runoff or from irrigation water" as expressed according to the units given in the published RIGW map. Similarly, the moderate to low and very low groundwater potential classes confirm and coincide with the previously published classes of the hydrogeologic map of Egypt (RIGW 1999), where they are equivalent to the RIGW units of "local and moderately

Table 6 Model validation using measured well yield data

\begin{tabular}{|c|c|c|}
\hline $\begin{array}{l}\text { Groundwater } \\
\text { prospects arrived } \\
\text { through the WSPM }\end{array}$ & Site location & Actual yield $\mathrm{m}^{3} /$ day \\
\hline \multirow[t]{7}{*}{ Very high } & $\begin{array}{l}\text { El-Arish (North Sinai) (shallow and } \\
\text { deep Quaternary aquifers) }\end{array}$ & 60,000 \\
\hline & $\begin{array}{l}\text { Sheikh Zuwaid (North Sinai) (shallow } \\
\text { and deep Quaternary aquifers) }\end{array}$ & 19,800 \\
\hline & $\begin{array}{l}\text { Rafah (North Sinai) (shallow and deep } \\
\text { Quaternary aquifers) }\end{array}$ & 20,000 \\
\hline & $\begin{array}{l}\text { Central, eastern and western Sinai deep } \\
\text { Nubia Sandstone aquifers of Lower } \\
\text { Cretaceous }\end{array}$ & \\
\hline & $\begin{array}{l}\text { Wadi Feiran wells and spring with a } \\
\text { catchment of } 170 \mathrm{~km}^{2} \text { with annual } \\
\text { precipitation of } 50 \mathrm{~mm} \text { (water in } \\
\text { alluvial lacustrine deposits and fracture } \\
\text { systems traversing the wadi bed) }\end{array}$ & $3,332.3$ \\
\hline & $\begin{array}{l}\text { Wells drilled in the alluvial fan of El } \\
\text { Qaa Plain, where the water appears } \\
\text { near the surface in numerous shallow } \\
\text { and drilled wells }\end{array}$ & $5,550.55$ \\
\hline & $\begin{array}{l}\text { Springs and wells of St. Catherine area } \\
\text { (Wadi Arbain with a catchment area } \\
\text { of } 12 \mathrm{~km}^{2} \text { and annual precipitation } \\
\text { of } 50 \mathrm{~mm} \text { ) }\end{array}$ & Prolific \\
\hline High to moderate & $\begin{array}{l}\text { Ain Furtaga in fractured granite feeding } \\
\text { alluvial aquifer of Wadi Watir (the } \\
\text { largest spring in the crystalline province) }\end{array}$ & Prolific \\
\hline Moderate to low & $\begin{array}{l}\text { El-Hassana, Maghara and Nekhil (central } \\
\text { Sinai), Ain Gedirat at NE El Qussaima } \\
\text { and Ain Qedis occurring near the eastern } \\
\text { international borders, northeastern coastal } \\
\text { zone of the Gulf of Suez }\end{array}$ & $\begin{array}{l}\text { 1,834 (Ayun Mussa), } 510 \text { (Ayun Mussa) 1,245.6 } \\
\text { (El Hassana), 1,440 (Nekhil), 1,440 (El Qussaima), } \\
\text { 1,440 (Ain Gedirat), } 960 \text { (Monbateh), } 840 \text { (Gifgafa), } \\
\text { 696 (Um Katf), 450 (Ras Missala), 120 (Ain Qedis), } \\
\text { + few wells with low productivity and higher salinity }\end{array}$ \\
\hline Low to very low & $\begin{array}{l}\text { Central Sinai extreme southern Sinai with } \\
\text { extremely arid climate (ave. annual } \\
\text { precipitation is }<10 \mathrm{~mm} \text {; i.e. Sharm El } \\
\text { Sheikh), Bir Nabq dug in alluvial fan of } \\
\text { Wadi Umm Adawi (small area of lower } \\
\text { rainfall). Vicinity of Ras Sudr-Ayun Mussa } \\
\text { (NE coastal zone of the Gulf of Suez) }\end{array}$ & Nil \\
\hline
\end{tabular}


to low productive aquifers". The moderate groundwater potential class of the present work could also be correlated with the RIGW unit of "extensive and moderately to low productive aquifers with paleokarstified features containing fossil water".

The validity of the WSPM developed was also checked against the borehole yield data, which reflect the actual groundwater potential. Table 6 shows that the groundwater potential zones obtained through this model have a good agreement with the actual borehole yield data obtained from different sources (NARSS 2009 and references therein; Table 6). Thus, the generated map can be used in the future as a preliminary confidential reference in selecting well sites and in land-use planning for groundwater protection.

\section{Summary and conclusion}

This study represents a modeling approach to integrate the physical and geologic factors governing groundwater potentiality, and thus to reveal the resulting information in a map form showing spatial data for areas with different responses to groundwater potentiality in the Sinai Peninsula. The map produced is an important component needed for the sustainable development of Sinai. Contributions of RS, GIS, WMS and WSPM as modern applied techniques were found to be highly effective in the construction of the concerned map. Eight pertinent thematic layers were introduced, for the first time, to build the WSPM layers, which gave a high accuracy for the map. These layers are rainfall, net groundwater recharge, lithology, lineaments density, drainage density, depth to water table, groundwater quality and terrain slope. Hence The WSPM was checked and validated by comparison with the published hydrogeological map of Egypt and actual borehole yield data and it was found that it correlates well with the previously published data and maps. This illustrates that the approach outlined has merits and can be successfully used elsewhere with appropriate modifications. The resulting groundwater potentiality map of Sinai indicates that the different geographic locations are suitable for groundwater storage with different magnitudes and potentialities, but the overall groundwater potential is the moderate class. Several promising drainage basins that have higher runoff were predicted to have high/moderate groundwater potential through the performed WMS. These basins could be the main source of contribution to sustainable recharge of the aquifer systems of Sinai. From this point of view, harvesting the overland flow or lost runoff water from the promising drainage basins (i.e. Wadies El Arish, Feiran, Alaawag, Gerafi, Dahab, Sidri and Watir) by implementing commonly used structures such as percolation tanks, check dams, subsurface dams and injection wells, becomes of utmost necessity. Storage of water as groundwater is the best method of resource enhancement as it not only involves filtration of surface water, but it reduces losses from evaporation, natural catastrophes etc. The use of these structures, to augment the groundwater resource, should become a sustainable strategy for the development of Sinai.

Acknowledgments This study was supported and funded by the National Authority for Remote Sensing and Space Sciences (NARSS), Cairo, Egypt. We thank the North Sinai Information Center for providing access to the up-to-date unpublished water resources reports. The authors are grateful for the thorough reviews by Dr. Shemin Ge (Editor) and Sue Duncan (Technical Editorial Advisor) of Hydrogeology Journal and the anonymous reviewers. Their comments significantly improved the quality of the paper.

\section{References}

Abd El Rahman H (2001) Evaluation of groundwater resources in Lower Cretaceous aquifer system in Sinai. Water Resour Manage 15(3):187-202

Abu Rayan M, Djebedjian B, Khaled I (2001) Water supply and demand and a desalination option for Sinai, Egypt. Desalination $136: 73-81$

AQUAVEO (2008) Water modeling solutions. Support forum for watershed modeling system software (WMS). www.aquaveo. com. Cited August 2009

Becker D, Sultan M, Becker R, Milewski A, Soliman F, Abdeldayem AW, Balekai R, Rashed M (2007) An integrated approach for the assessment of the renewable ground water resources of Sinai, Egypt. Geol Soc Am Abst 39(6):482

Chen $\mathrm{Cl}$ (1982) An evaluation of the mathematics and physical significance of the soil conservation service curve number procedure for estimating runoff volume. In: Singh VP (ed) Rainfall-runoff relationship. Water Resources, Littleton, CO, pp $487-515$

CONOCO (Continental Oil Company) (1987) Geological Map of Egypt (Scale 1: 500,000). Conoco Inc., Ogden, UT, in collaboration with Freie Universitat Berlin, Berlin, Germany

Das D (2000) GIS application in hydrogeological studies. Available via www.gisdevelopment.net. Cited August 2009

De Roo APJ (2000) Applying the LISEM model for investigating flood prevention and soil conservation scenarios in SouthLimburg, The Netherlands. In: Schmidt J (ed) Soil erosion: application of physically based models. Springer, Heidelberg, $318 \mathrm{pp}$

Degnan P, Clark H (2002) Fractured-correlated lineaments at Great Bay, southeastern New Hampshire. US Geol Surv Open-File Rep 02-13, 14, 1 plate

Doll P, Lehner B, Kaspar F (2002) Global modeling of groundwater recharge. 399 Proceedings of 3rd International Conference on Water Resources and the Environment Research, vol 1. Technical University of Dresden, Germany, pp 27-33

Edet A, Okereke S, Teme C, Esu O (1998) Application of remote sensing data to groundwater exploration: a case study of the Cross River State, southeastern Nigeria. Hydrogeol J 6(3):394404

El-Baz F (1992) Preliminary observations of environmental damage due to the Gulf War. Nat Resour Forum 16(1):71-75

El-Baz F et al. (1992-1995) Research project. Groundwater potential of the Sinai Peninsula, Egypt. http://www.bu.edu/ remotesensing/research/completed/egypt-groundwater/. Cited June 2010

El-Shazly EM, Abdel Hady MA, El Ghawaby MA, Salman AB, El Rakaiby MM, El Aasy IE (1980) Structural lineation maps of Sinai, scale 1:250, 000. Academy of Scientific Research and Technology, Remote Sensing Center, Cairo

El-Shazly M, El Rakaiby M, El Kassas M (1983) Groundwater investigation of Wadi Araba area, Eastern Desert of Egypt, Using Landsat Imagery. Proc. 17th Symp. on Remote Sensing of the Environment. Ann Arbor, MI, 9-13 May 1983, pp10031113 
El-Shazly EM, Mohamed SS, Abd Alatif TA, Misak R, Mabrouk MA (1985) Groundwater potential of St Catherine Monastery Environs, Sinai, Egypt. J Geol 11:89-100

ESRI (2007) ArcGIS 9.2 Software and user manual. Environmental Systems Research Institute, Redlands, CA. http://www.esri.com. Cited June 2009

Fetter CW (1994) Applied hydrogeology, 3rd edn. Prentice Hall, Upper Saddle River, NJ, 691 pp

Garbrecht J, Martz LW (1997) TOPAZ: an automated digital landscape analysis tool for topographic evaluation, drainage identification, watershed segmentation and subcatchment parameterization; TOPAZ Overview, USDA, ARS Publication no. GRL 97-3, Agricultural Research Service, Grazing lands Research Laboratory, El Reno, OK

Gheith H, Sultan M (2000) Assessment of the renewable ground water resources of Sinai, Egypt using remote sensing, digital terrain elevation, and meteorological data. Symposium of Remote Sensing and Hydrology 2000, International Commission on Remote Sensing for Hydrology, Santa Fe, NM

Gheith H, Sultan M (2001) Assessment of the renewable groundwater resources of Wadi El-Arish, Sinai, Egypt: Modeling, remote sensing and GIS applications. In: Owe M et al. Proc. of a Symposium on Remote Sensing and Hydrogeology. IAHS Publ. 267, IAHS, Wallingford, UK, pp 451-454

Hjelmfelt AT Jr (1980) Curve-number procedure as infiltration method. J Hydraul Div ASCE 106:1107-1111

Hogarth WL, Rose CW, Parlange JY, Sander GC, Carey G (2004) Soil erosion due to rainfall impact with no inflow: a numerical solution with spatial and temporal effects of sediment settling velocity characteristics. J Hydrol 294:229-240

Holtan HN (1961) A concept for infiltration estimates in watershed engineering. USDA Agricultural Research Service Publication: ARS-41-51, USDA, Agricultural Research Service, Grazing lands Research Laboratory, El Reno, OK

Horton RI (1938) The interpretation and application of runoff plot experiments with reference to soil erosion problems. Proc Soil Sci Soc Am 3:340-349

ICG (International Crisis Group) (2007) Egypt's Sinai question. Middle East/North Africa Report no. 61, ICG, Brussels, 32 pp. www.ciaonet.org/wps/icg431/icg431.pdf. Cited June 2009

Isaaks EH, Srivastava RM (1989) An introduction to applied geostatistics. Oxford University Press, New York, 561 pp

Issar AS, Bein A, Michaeli A (1972) On the ancient water of the Upper Nubian sandstone aquifer in central Sinai and southern Israel. J Hydrol 17:353-374

Jain MK, Kothyari UC, Ranga Raju KG (2005) Geographic information system based distributed model for soil erosion and rate of sediment outflow from catchments. J Hydraul Eng ASCE 131(9):755-769

JICA (Japan International Cooperation Agency) (1999) South Sinai groundwater resources study report. Pacific Consultants International and Sanyu Consultants Inc., Tokyo

Kusky T, El-Baz F, Morency R, Himida I (1994) Remote sensing aids to groundwater exploration in fractured rocks of the Sinai Peninsula. Harvest 1:3-4

Leica Geosystems GIS, Mapping LLC (2008) ERDAS Field Guide, vol 1. Leica Geosystems Geospatial Imaging, Norcross, GA

MASOUD A, Koike K (2005) Remote sensing and GIS integration for groundwater potential mapping in Sinai Peninsula, Egypt. Proceedings of International Association for Mathematical Geology (IAMG'05): GIS and Spatial Analysis, vol 1, 21-26 Aug 2005, Toronto, pp 440-445
Milewski A, Yan E, Sultan M, Abdeldayem AW, Gelil KA, Becker R, Markondiah Jayaprakash S (2006) A catchment based hydrologic model for the Sinai Peninsula using remote sensing and field datasets, EOS Trans AGU, 87(36), Jt. Assem. Suppl., Abstract H43B-11

Mills AC, Shata A (2009) Ground-water assessment of Sinai, Egypt. Groundwater 27(6):793-801

Mishra SK, Singh V P (2003) Soil Conservation Service Curve Number (SCS-CN) Methodology. Kluwer, Dordrecht, The Netherlands, pp 2-4

Mishra SK, Singh VP (2004a) Validity and extension of the SCS$\mathrm{CN}$ method for computing infiltration and rainfall-excess rates. $\mathrm{J}$ Hydrol Process 18:3323-3345

Mishra SK, Singh VP (2004b) Long term hydrological simulation based on the soil conservation service curve number. J Hydrol Process 18(7):1291-1313

Moore G, Waltz FA (1986) Objective procedure for lineament enhancement and extraction. Photogramm Eng Rem Sens 49:641-647

Ponce VM, Hawkins RH (1996) Runoff curve number: Has it reached maturity? Hydrol Eng ASCE 1(1):11-19

RIGW (Research Institute for Groundwater) (1999) Hydrogeological map of Egypt. Scale 1:2,000,000, 2nd edn. National Water Research Center (NWRC), Ministry of Public Works and Water Resources, Cairo

Robinson C, El-Baz F, Singhory V (1999) Subsurface imaging by RADARSAT: comparison with Landsat TM data and implications for groundwater in the Selima area, northwestern Sudan. Rem Sens Abst 25(3):45-76

SCS (1956) National Engineering Handbook, Hydrology, sec.4. Soil Conservation Service, USDA, Washington, DC

Sener E, Davraz A, Ozcelik M (2005) An integration of GIS and remote sensing in groundwater investigations: a case study in Burdur, Turkey. Hydrogeol J 13(5):826-834

Shata A (1956) Structural development of the Sinai Peninsula, Egypt. Bull de L' Inst. Desert. d' Egypt, Cairo

Shata A (1992) Watershed management, development of potential water resources and desertification control in Sinai. Proceedings of the 3rd Conference on the Geology and Development of Sinai, Ismailia, Egypt, Dec. 2007, pp 273-280

Smith SE, El-Shamy I, Abd-El Monsef H (1997) Locating regions of high probability for groundwater in the Wadi EI-Arish Basin, Sinai, Egypt. J Afr Earth Sci 25(2):253-262

Teeuw R (1995) Groundwater exploration using remote sensing and a low-cost geographic information system. Hydrogeol J 3 (3):21-30

Tucker GE, Bras RL (1998) Hill slope processes, drainage density, and landscape morphology. Water Resour Res $34: 2751-2764$

Tyagi JV, Mishra SK, Singh R, Singh VP (2008) SCS-CN based time-distributed sediment yield model. J Hydrol 352:388403

UNDP (United Nations Development Program)/GEF funded project (2003-2008), Renewable groundwater resources in Sinai. UNDP, New York. http://www.esrs.wmich.edu/htm/sinai_water.html. Cited June 2010

Van Engelen VWP, Wen TT (1995) Global and national soils and terrain digital databases (SOTER). Procedures manual (revised edn.). International Soil References and Information Centre, Wageningen, The Netherlands 